\title{
Peningkatan Pencapaian dalam Pecahan: Kerangka Konseptual untuk Pembelajaran Berasaskan Permainan Digital Menggunakan Minecraft
}

\author{
Enhancement of Achievement in Fractions: A Conceptual Framework for Digital \\ Game-Based Learning using Minecraft
}

\author{
Rayner Bin Tangkui ${ }^{1 *}$, Tan Choon Keong ${ }^{2}$ \\ ${ }^{1}$ Fakulti Psikologi dan Pendidikan,Universiti Malaysia Sabah; raynertangkui@gmail.com \\ ${ }^{2}$ Fakulti Psikologi dan Pendidikan, Universiti Malaysia Sabah; cktanums@gmail.com \\ * Corresponding author
}

To cite this article (APA): Tangkui, R., \& Tan, C. K. (2020). Peningkatan pencapaian dalam pecahan: Kerangka konseptual untuk pembelajaran berasaskan permainan digital menggunakan Minecraft. Journal of ICT in Education, 7(2), 39-53. https://doi.org/10.37134/jictie.vol7.2.4.2020

To link to this article: https://doi.org/10.37134/jictie.vol7.2.4.2020

\begin{abstract}
Abstrak
Kemajuan pesat teknologi maklumat dan komunikasi (TMK) telah membawa kepada berkembangnya inovasi dan kecanggihan permainan digital. Pelbagai kajian menunjukkan bahawa pembelajaran berasaskan permainan digital adalah berkesan dalam menggalak keterlibatan, motivasi, minat serta peningkatan pencapaian murid dalam pembelajaran. Di samping itu, pembelajaran berasaskan permainan digital juga mampu menyemai kemahiran abad ke-21 seperti kreativiti, komunikasi, kolaborasi dan kemahiran berfikir aras tinggi (KBAT). Namun demikian, laporan Trends in Mathematics and Science Study (TIMSS) dan Programme for International Student Assessment (PISA) menunjukkan bahawa pencapaian murid Malaysia dalam matematik khususnya yang berkaitan dengan pecahan adalah kurang memuaskan iaitu berada di bawah skor purata antarabangsa. Pembelajaran berasaskan permainan digital yang mengaplikasi Minecraft dilihat mempunyai potensi untuk meningkatkan pencapaian murid dalam pecahan. Dengan itu, objektif kertas konsep ini adalah untuk membincangkan kerangka konsep bagi pembangunan persekitaran pembelajaran maya (virtual learning environment) melalui pembelajaran berasaskan permainan digital yang mengaplikasi Minecraft bagi meningkatkan pencapaian murid dalam pecahan.
\end{abstract}

Kata Kunci: pembelajaran berasaskan permainan digital, Minecraft, pecahan.

\section{Abstract}

The rapid advancement in information and communication technology (ICT) has led to the increase in digital games innovation and sophistication. Numerous studies have shown that digital game-based learning is able to effectively encourage engagement, motivation, interest as well as increasing pupils' 
achievement in learning. In addition, digital game-based learning can also cultivate 21 st-century skills such as creativity, communication, collaboration and higher order thinking skills (HOTS). However, the reports in Trends in Mathematics and Science Study (TIMSS) and the Program for International Student Assessment (PISA) have shown that the achievement of Malaysian pupils in mathematics especially in relation to fractions is not satisfactory, which is below the international average score. Digital game-based learning which applies Minecraft has been seen to have the potential in improving pupils' achievement in fractions. Thus, the objective of this concept paper is to discuss the conceptual framework for the development of a virtual learning environment through digital game-based learning that applies Minecraft in order to increase pupils' achievement in fractions.

Keywords: digital game-based learning, Minecraft, fractions.

\section{PENGENALAN}

TMK telah menjadi suatu bentuk teknologi yang penting terutama dalam era ledakan maklumat masa kini. Pengaruh TMK bukan sahaja dapat dilihat dalam bidang yang berkaitan dengan pentadbiran dan ekonomi tetapi juga dalam bidang pendidikan. Pengaruh TMK dalam bidang pendidikan dapat dilihat secara spesifik melalui integrasi TMK dalam sesi pengajaran dan pemudahcaraan (PdPc). Pelaksanaan PdPc yang di integrasi dengan TMK seperti penggunaan permainan digital merupakan antara inisiatif penting yang perlu diberi perhatian dalam usaha mewujudkan persekitaran pembelajaran yang lebih menarik, menggalakkan keterlibatan aktif serta memotivasikan murid untuk mengikuti sesi PdPc yang disampaikan guru. Pengintegrasian TMK dalam PdPc adalah penting bagi memberi nilai tambah kepada sesi PdPc agar mampu mewujudkan kaedah baru dan inovatif dalam penyampaian pengajaran.

\section{PENYATAAN MASALAH}

Pecahan merupakan salah satu konsep yang penting dalam matematik namun turut dianggap sebagai antara konsep yang kompleks. Kemampuan untuk memahami dan menguasai konsep pecahan dengan baik akan menyediakan asas yang kukuh bagi membentuk dan mengembangkan idea matematik (Zakiah, Norhapidah, Mohamad Nizam, Hazaka \& Effandi., 2013), menguasai konsep matematik yang lebih kompleks seperti konsep algebra (Booth, Newton \& Twiss-Gritty, 2014) dan membantu dalam penyelesaian masalah yang dihadapi dalam kehidupan seharian khususnya yang melibatkan pengiraan dan pengukuran seperti peratus, nisbah, kadar serta perpuluhan (Abdul Halim, Nur Liyana \& Marlina, 2015; Booth \& Newton, 2012; Ndalichako, 2013; Wijaya, 2017). Di Malaysia, topik pecahan telah mula diperkenalkan kepada murid sejak dari peringkat sekolah rendah lagi iaitu di Tahun Satu (Kementerian Pendidikan Malaysia, 2015). Pecahan merupakan salah satu topik dalam bidang Nombor dan Operasi yang diajar selepas topik nombor bulat. Objektif pembelajaran pecahan di sekolah rendah adalah penguasaan terhadap konsep asas pecahan, operasi pecahan iaitu tambah, tolak, darab, bahagi serta pengaplikasian pengetahuan dan kemahiran pecahan dalam penyelesaian soalan berbentuk rutin dan bukan rutin. 
Walaupun topik pecahan telah diperkenalkan sejak dari peringkat awal lagi, murid Malaysia masih menghadapi kesukaran untuk memahami dan menguasai konsep pecahan dengan baik. Laporan International Association for the Evaluation of Educational Achievement (IEA) dan Organisation for Economic Co-operation and Development (OECD) berkaitan pencapaian literasi matematik murid Malaysia dalam pentaksiran antarabangsa iaitu Trends in Mathematics and Science Study (TIMSS) dan Programme for International Student Assessment (PISA) menunjukkan bahawa kebanyakan murid Malaysia belum memperoleh tahap pencapaian yang memuaskan dalam matematik sehingga menyumbang kepada kemerosotan kedudukan Malaysia berbanding negara lain dari segi penguasaan literasi (Mullis, Martin, Foy \& Arora, 2012; Mullis, Martin, Foy \& Hooper, 2016; Nor'ain \& Mohan Chinnappan, 2016; OECD 2013). Skala pencapaian TIMSS meletakkan pencapaian murid pada empat tahap penanda aras berdasarkan skor purata yang diperoleh berdasarkan Jadual 1.

Jadual 1: Tahap penanda aras antarabangsa dan skor purata

\begin{tabular}{lc}
\hline \multicolumn{1}{c}{ Tahap Penanda Aras } & Skor Purata \\
\hline Penandaarasan antarabangsa tertinggi & 625 \\
Penandaarasan antarabangsa tinggi & 550 \\
Penandaarasan antarabangsa sederhana & 475 \\
Penandaarasan antarabangsa rendah & 400 \\
\hline Sumber: Mullis et. al. (2016) &
\end{tabular}

Dalam PISA 2012, Malaysia mendapat skor literasi matematik 421. Skor ini berada di bawah purata skor OECD (494) dan skor purata antarabangsa (548). Dengan memperolehi skor ini, Malaysia berada di kedudukan ke 52 daripada 65 buah negara yang mengambil bahagian dan berada di bawah negaranegara Asia Tenggara seperti Singapura (573), Vietnam (511) dan Thailand (427) (Abdul Halim et. al., 2015; OECD, 2013, 2010). Kerangka pentaksiran TIMSS bagi literasi matematik adalah terdiri daripada soalan matematik yang mentaksir domain Nombor dan pecahan merupakan tajuk yang terdapat dalam domain Nombor.

Salah satu faktor yang menyebabkan murid Malaysia mempunyai pengetahuan dan kefahaman konsep pecahan yang kurang memuaskan adalah miskonsepsi nombor bulat yang juga dikenali sebagai Whole Number Bias (Ni \& Zhou, 2005) atau Natural Number Bias (Alibali \& Sidney, 2015). Miskonsepsi nombor bulat berlaku kerana murid menganggap bahawa konsep nombor bulat boleh diaplikasikan ke atas pecahan kerana konsep nombor bulat dan konsep pecahan adalah sama (Lamon, 2008; Siegler \& Pyke, 2013). Murid cenderung mengeneralisasikan pengetahuan dan kemahiran yang dipelajari daripada topik nombor bulat ke topik pecahan walaupun dari struktur nombor bulat adalah berbeza dengan struktur pecahan (Van de Walle, Karp \& Bay-Williams, 2019). Miskonsepsi ini akan memberi kesan terhadap pengetahuan dan pemahaman konsep pecahan di kalangan murid disebabkan murid menganggap bahawa pengangka dan penyebut adalah dua nombor bulat yang berasingan dan bukannya dua nombor yang saling berkait antara satu sama lain (DeWolf \& Vosniadou, 2015). Berdasarkan dapatan ini, terdapat keperluan untuk menangani miskonsepsi ini bagi memperkukuh pengetahuan dan pemahaman murid terhadap konsep pecahan sekali gus meningkatkan pencapaian murid Malaysia. 


\section{TINJAUAN LITERATUR}

\section{Permainan Digital}

Permainan digital telah menjadi sumber hiburan sejak beberapa dekad yang lalu dan akan terus menjadi sumber hiburan di masa akan datang (Sailer, Hense, Mayr \& Mandl, 2017). Entertainment Software Association (2019) menganggarkan bahawa jualan permainan digital pada tahun 2018 adalah melebihi nilai 43.4 bilion USD. Permainan digital dimainkan oleh sebanyak 164 juta atau $65 \%$ penduduk dewasa di Amerika Syarikat. Di Malaysia, nilai eksport yang dihasilkan oleh lebih 60 buah studio pembangun permainan digital tempatan adalah berjumlah RM600 juta (The Star, 2019). Nilai-nilai ini jelas menunjukkan bahawa permainan digital sememangnya mendapat permintaan yang tinggi dan berupaya menjana pulangan pendapatan yang baik. Melihat kepada keupayaan permainan digital dalam menarik minat dan perhatian murid serta pelajar, golongan pendidik sudah mula mengambil inisiatif untuk mengintegrasikan permainan digital ke dalam persekitaran pendidikan.

Dirujuk menggunakan istilah game, Prensky (2001) mendefinisikan game sebagai sesuatu yang berasaskan kepada konsep keseronokan. Salen dan Zimmerman (2004) mendefinisikan game sebagai sebuah sistem yang mencetus keterlibatan pemain-pemainnya dalam suatu konflik tiruan (artifical conflict), ditakrifkan oleh peraturan serta menghasilkan hasil (outcomes) yang boleh diukur. Noor Azli, Nor Azan dan Shamsul Bahri (2008) mendefinisikan permainan digital sebagai permainan komputer atau video dalam bentuk aplikasi digital yang boleh dikawal oleh pemain atau sekumpulan pemain menggunakan peranti mudah alih seperti telefon pintar dan tablet. Bagi skop kertas konsep ini, permainan digital didefinisikan sebagai suatu sistem interaktif yang mempunyai peraturan, cabaran dan matlamat yang berupaya mencetus keterlibatan pemain-pemain dengan adanya ciri-ciri hiburan, maklum balas berterusan (constant feedback) dan perkembangan (progress) ke arah matlamat tersebut selaras dengan definisi yang diketengahkan oleh Bhuiyan dan Mahmud (2015).

Apabila membincangkan mengenai permainan digital, salah satu aspek yang perlu diperincikan adalah perbezaan antara jenis permainan (game type) dengan genre permainan (game genre). Setiap permainan digital dibezakan berdasarkan judul, bentuk interaksi dengan pemain, kaedah permainan dan gaya penceritaan. Menurut Grace (2005), jenis permainan merujuk kepada ciri-ciri gameplay sesebuah permainan digital. Gameplay merujuk kepada keseluruhan pengalaman yang dialami pemain semasa berinteraksi dengan permainan digital (Rollings \& Adams, 2003). Pengalaman yang dialami kesan interaksi dengan permainan digital adalah dipengaruhi oleh elemen dan komponen seperti aspek taktikal permainan digital berkenaan, plot, peraturan, cabaran, objektif dan cara mencapai objektif tersebut, aktiviti yang dilaksanakan dalam dunia maya permainan digital serta game mechanics (Adams \& Dormans, 2012; Adams, 2010; Fabricatore, Nussbaum \& Rosas, 2002; Salen \& Zimmerman, 2004). Jenis permainan adalah merangkumi aksi (action), pengembaraan (adventure), teka-teki (puzzle), main peranan (role play), simulasi (simulation) dan strategi (strategy). Genre permainan pula adalah merujuk kepada gaya penceritaan sesebuah permainan digital. Genre merupakan istilah yang lazim digunakan dalam bidang perfileman bagi membezakan gaya penceritaan 
antara satu filem dengan filem lain. Grace (2005) menyenaraikan sembilan genre permainan utama dan genre-genre ini merangkumi drama, jenayah, fantasi, seram, misteri, fiksyen sains, perang, pengintipan dan sejarah. Pengetahuan mengenai jenis permainan dan genre permainan adalah penting untuk memberi penjelasan mengapa permainan digital berupaya menarik perhatian dan minat pemain dari pelbagai lapisan masyarakat. Ini adalah kerana setiap individu masing-masing meminati jenis permainan dan genre permainan yang tertentu, dan ciri ini perlu diambil kira khususnya dalam kalangan golongan pendidik sebelum mengaplikasikan permainan digital sebagai alat pengajaran di bilik darjah.

\section{Pembelajaran Berasaskan Permainan Digital}

Melihat kepada persekitaran pendidikan masa kini, golongan pendidik sudah mula memberi perhatian dan menunjukkan minat terhadap permainan digital khususnya terhadap potensi permainan digital untuk diaplikasi dalam pelaksanaan pengajaran dan pemudahcaraan. Ini adalah kerana golongan pendidik mula menyedari bahawa permainan digital mempunyai keupayaan untuk menarik perhatian, menggalakkan keterlibatan (encourage engagement) serta bersifat immersive, iaitu berupaya mencetus penghayatan yang tinggi kepada pemainnya sehingga permainan digital tersebut dimainkan selama berjam-jam (Kirriemuir \& McFarlene, 2004). Kanak-kanak adalah termotivasi dan menunjukkan minat serta keterlibatan yang tinggi semasa memainkan permainan digital dan golongan pendidik khususnya guru ingin melihat sifat yang sama ditunjukkan oleh murid semasa mengikuti pembelajaran di bilik darjah (Peetsma \& Van der Veen, 2015). Dengan itu, terdapat usaha untuk mengintegrasi permainan digital di dalam pelaksanaan PdPc kerana mengambil kira kelebihan yang dapat diperolehi melalui penggunaan permainan digital sebagai alat bantu mengajar.

Menurut Huizenga (2017) serta Wong dan Kamisah (2018), tidak terdapat definisi yang spesifik untuk menjelaskan mengenai pembelajaran berasaskan permainan digital. Namun demikian, pembelajaran berasaskan permainan digital lazimnya di definisi berdasarkan beberapa ciri umum. Pembelajaran berasaskan permainan digital merupakan pendekatan pembelajaran berasaskan permainan digital (Prensky, 2001). All, Castellar \& Van Looy (2016) mendefinisikan pembelajaran berasaskan permainan digital sebagai penggunaan permainan digital untuk tujuan pendidikan, yang mengandungi kedua-dua elemen hiburan dan pendidikan. Wiggins (2016) menjelaskan pembelajaran berasaskan permainan digital sebagai penggunaan permainan digital dalam konteks pendidikan bagi tujuan mencapai objektif pembelajaran. Wang, Liu, Lin \& Xiang (2011) menyatakan bahawa pembelajaran berasaskan permainan digital merupakan penggunaan permainan digital untuk menjadikan suasana pembelajaran lebih menyeronokkan berbanding kaedah konvensional manakala menurut Al-Azawi, Al-Faliti dan Al-Blushi (2016), pembelajaran berasaskan permainan digital merupakan integrasi permainan digital dalam PdPc untuk meningkatkan pengalaman pembelajaran. Hwang, Chiu dan Chen (2015) serta Yang (2015) menyatakan bahawa konsep yang diketengahkan oleh kaedah pembelajaran ini adalah pendekatan belajar sambil bermain. 
Pembelajaran berasaskan permainan digital dapat dikenal pasti melalui beberapa ciri tertentu. Kaedah pengajaran ini menggabungkan ciri permainan (game features) dengan kandungan pengajaran dan dengan itu memberikan suatu bentuk alat bantu pembelajaran kepada murid. Ciri-ciri pembelajaran berasaskan permainan digital adalah mempunyai antara muka bergambar (pictorial interface) dan wujudnya cabaran yang mendorong murid untuk terlibat secara aktif dalam pembelajaran, sekali gus mencetus peningkatan motivasi untuk belajar dan hasil pembelajaran serta merangsang keseronokan dalam persekitaran yang menghiburkan (Bawa, Watson \& Watson, 2018). Dengan itu, pembelajaran berasaskan permainan digital berupaya menyediakan persekitaran pembelajaran yang efektif di mana murid dapat mengembangkan kemahiran dan pengetahuan asas dalam bidang-bidang tertentu selaras dengan perkembangan era teknologi digital (Hwang et. al., 2015). Secara umum, keberkesanan pembelajaran berasaskan permainan digital lazimnya bergantung murid untuk menetapkan sasaran yang ingin dicapai semasa menyelesaikan cabaran, memantau kemajuan untuk menentukan sama ada strategi yang digunakan adalah bersesuaian untuk mencapai sasaran serta bagi guru untuk melaksanakan pemantauan berterusan terhadap kemajuan murid semasa pembelajaran berasaskan permainan digital dan memberikan bimbingan serta sokongan berterusan kepada murid (Chen, 2017; Sung, Hwang, Lin \& Hong, 2017).

\section{Permainan Digital Minecraft}

Minecraft merupakan permainan digital 'dunia-terbuka' (open-world) di dalam persekitaran 'sandbox' yang merupakan salah satu permainan digital yang terlaris dalam sejarah. Permainan digital 'duniaterbuka' merupakan permainan digital di mana penerokaan dan penjelajahan dunia maya dilakukan oleh pemain tanpa adanya pengakhiran yang jelas atau sasaran yang perlu dicapai (Donellan, 2019). Dalam konteks Minecraft, pemain tidak mempunyai matlamat atau sasaran khusus untuk dicapai. Ini memberi kebebasan kepada pemain untuk memilih bagaimana untuk memainkan permainan digital tersebut. Persekitaran dunia Minecraft adalah terdiri daripada entiti berbentuk blok 3D dengan warna dan corak yang berbeza. Secara umum, pemain yang berada dalam persekitaran dunia maya Minecraft ini akan mengumpul (collecting), memecah (breaking), membina semula (reconstructing), mengalih (removing) dan meletak (placing) objek berbentuk blok 3D secara rawak dalam dunia maya tersebut, di mana perlakuan ini membolehkan pemain membentuk sebarang struktur atau binaan dengan manipulasi blok mengikut daya imaginasi pemain (Kim \& Park, 2018; Lane et. al., 2017; Ekaputra et. al., 2013; Nebel et. al., 2016; Mojang, 2015a; Bos et. al., 2014). Dalam mod Creative, pemain dibekalkan dengan pelbagai jenis blok serta bahan dan sumber seperti pedang, cangkul, air, tanah, bahan letupan, api dan sebagainya (Gallagher, 2015). Namun demikian, dalam meneroka dunia maya Minecraft, pemain juga berupaya untuk mencari dan mengumpul sumber bahan yang boleh digunakan untuk menghasilkan sesuatu peralatan, objek atau struktur. Melalui daya kreativiti serta imaginasi, pelbagai peralatan, objek dan struktur boleh dihasilkan dengan sumber atau bahan yang ditemukan tersebut yang masing-masing mempunyai fungsi dan peranan tertentu dalam dunia maya berkenaan.

Minecraft merupakan salah satu daripada permainan digital yang digunakan sebagai alat pengajaran untuk pelbagai topik dan subjek di seluruh dunia (Minecraft Teachers, 2015; Short, 2012). Penerimaan guru dan golongan pendidik bahawa Minecraft berpotensi dijadikan alat pengajaran menandakan bahawa Minecraft telah pun diaplikasi dalam persekitaran sekolah (Callaghan, 2016; Nebel et. al., 
2016; Mail, 2015; Sáez-López et. al., 2015; Cipollone et. al., 2014). Sekolah-sekolah di Amerika dan Sweden telah mengintegrasi Minecraft ke dalam kurikulum mereka sejak tahun 2013 (Karsenti et. al., 2017). Minecraft telah diintegrasi ke dalam pelaksanaan PdPc untuk menyokong pembelajaran STEM (Lane et. al., 2017), geometri (Kim \& Park, 2018; Bos et. al., 2014), bahasa dan literasi (Lyngstad, 2017; Bebbington, 2014; Garcia Martinez, 2014; Hanghøj et. al., 2014), kesusasteraan (Cipollone et. al., 2014), penceritaan digital (Garcia Martinez, 2014), kemahiran sosial (Petrov, 2014), aplikasi seni komputer (Garcia Martinez, 2014) dan pengurusan projek (Saito et. al., 2014). Terdapat banyak aspek dalam Minecraft yang dapat dijadikan alat pengajaran yang berkesan dan dalam masa yang sama adalah menyeronokkan.

\section{Kajian Lepas Berkenaan Pembelajaran Berasaskan Permainan Digital Menggunakan Minecraft}

Pelbagai kajian berkenaan pembelajaran berasaskan permainan digital telah dijalankan yang melibatkan pelbagai subjek seperti Bahasa Inggeris (Yeh, Hung \& Hsu, 2017), Geografi (Khairuddin et. al., 2017), Matematik (Ku et. al., 2014), Sains (Hwang, Hung \& Chen, 2014) dan Fizik (Kao et. al., 2017). Kajian berkenaan penggunaan pembelajaran berasaskan permainan digital dalam menyokong kreativiti juga turut dijalankan (Behnamnia et. al., 2020). Dapatan kajian-kajian berkenaan pembelajaran berasaskan permainan digital menunjukkan kesan positif terhadap pembelajaran murid. Kesan positif seperti menggalakkan kolaborasi (Asselstine et. al., 2015), meningkatkan kemahiran penyelesaian masalah (Chen, Liao \& Chang, 2015; Hwang et. al., 2014; Gee, 2003), meningkatkan prestasi dan keyakinan murid (Ku et. al., 2014) dan menarik minat terhadap pembelajaran (Liu \& Chen, 2013; Nazirah et. al., 2013) jelas membuktikan bahawa permainan digital yang diaplikasi dalam PdPc berpotensi digunakan dalam persekitaran pendidikan.

\section{KERANGKA KONSEPTUAL PEMBELAJARAN BERASASKAN PERMAINAN DIGITAL MENGGUNAKAN MINECRAFT}

Dalam melaksanakan kajian ini, teori pembelajaran yang terdiri daripada teori main, teori connectionism, teori konstruktivisme kognitif, teori konstruktivisme sosial dan teori rangsangan deria serta elemen 'dunia terbuka' Minecraft digabung bagi membentuk kerangka konseptual kajian ini.

\section{Teori Pembelajaran}

Beberapa teori pembelajaran telah dirujuk dalam usaha membangunkan kerangka konsep pembelajaran berasaskan permainan digital yang akan menyokong peningkatan pencapaian murid dalam pecahan. Rujukan terhadap teori pembelajaran di buat oleh kerana teori pembelajaran berupaya membantu dalam memahami asas masalah pembelajaran dan memberi panduan yang berkesan dan bersesuaian untuk menyelesaikan masalah yang dihadapi murid dengan membuat penilaian, menyemak bahan serta mengenal pasti teknik dan kaedah yang boleh digunakan untuk membantu murid. Teori pembelajaran yang dirujuk merangkumi teori main, teori connectionism, teori konstruktivisme kognitif, teori konstruktivisme sosial dan teori rangsangan deria (sensory stimulation 
theory). Teori main yang dipelopori oleh Piaget dan Vygotsky telah dirujuk memandangkan keduadua tokoh ini membincangkan secara spesifik ciri-ciri main yang berkaitan dengan perkembangan kognitif iaitu melalui perubahan peringkat main dan interaksi sosial (Van Hoorn et. al., 2007). Teori connectionism menjelaskan bahawa murid akan lebih bersemangat untuk belajar sekiranya mengetahui akan mendapat sesuatu yang baik seperti ganjaran dan pembelajaran akan lebih berkesan apabila latihan dilakukan secara berulang-ulang dalam jumlah yang banyak. Teori konstruktivisme kognitif adalah teori pembelajaran yang menyatakan bahawa pengetahuan yang diperoleh semasa proses pembelajaran dibina berdasarkan pengalaman yang diperoleh dari proses pembelajaran sebelumnya. Murid perlu membina pengetahuan baru secara aktif berdasarkan pengalaman yang telah dimiliki sebelum ini atau pengalaman sedia ada manakala peranan guru atau pendidik adalah membimbing serta menyediakan sumber atau bahan yang bersesuaian dengan keperluan murid (Dagar \& Yadav, 2016). Teori konstruktivisme sosial adalah teori pembelajaran yang menyatakan bahawa pengetahuan dibina melalui interaksi sosial. Berdasarkan teori ini, pengetahuan dan idea seseorang murid terbina melalui interaksi dengan guru atau murid lain manakala teori rangsangan deria menjelaskan bahawa sebagai sebuah sistem interaktif, permainan digital berupaya merangsang lebih dari satu deria semasa pembelajaran dan semakin banyak deria dirangsang, semakin banyak maklumat dapat diproses melalui deria-deria dan dengan itu memberi lebih banyak input kepada murid untuk diperoleh, diproses, dikaitkan dan ditafsir sehingga membolehkan murid lebih memahami sesuatu konsep yang disampaikan serta mengekalkan pengetahuan konsep tersebut dengan lebih lama dalam minda yang dapat dikeluarkan semula (recall) apabila diperlukan untuk menyelesaikan masalah yang dihadapi (Obaid, 2013; Shabiralyani, Hasan, Hamad \& Iqbal, 2015).

\section{Pembelajaran Pecahan Menggunakan Minecraft}

Kajian Rodrigues et. al. (2017) serta Siegler \& Pyke (2013) mendapati bahawa murid menghadapi kesukaran untuk memahami konsep utama pecahan khususnya konsep hubungan pengangka dengan penyebut serta konsep pecahan setara. Murid melihat pecahan sebagai sepasang nombor (pengangka dan penyebut) yang mewakili kuantiti tertentu tanpa adanya hubungan antara kedua-dua kuantiti tersebut (Stafylidou \& Vosniadou, 2004). Kesukaran untuk memahami konsep pecahan yang abstrak telah menyebabkan murid tidak mempunyai pemahaman dan pengetahuan konseptual pecahan yang mendalam dan kukuh (Zakiah et. al., 2013; Simon et. al., 2018). Minecraft dilihat berpotensi untuk digunakan dalam pembelajaran pecahan terutama dalam mengukuhkan pemahaman dan pengetahuan konseptual pecahan disebabkan Minecraft membolehkan aktiviti berbentuk 'hands-on' dilakukan melalui manipulasi ke atas blok, peralatan serta bahan yang terdapat dalam dunia maya Minecraft. Blok tersebut dapat disusun dengan cara yang dapat menghasilkan struktur atau objek yang mewakili pecahan. Struktur atau objek yang dihasilkan bagi mewakili pecahan akan membantu murid memvisualisasi nilai pecahan dengan lebih jelas dan ini akan membantu murid untuk mempunyai pemahaman konseptual pecahan yang lebih baik. Sebagai contoh, satu blok berwarna kuning yang diletakkan di atas satu blok lutsinar boleh mewakili pecahan dengan nilai 'satu per dua' seperti yang ditunjukkan dalam Rajah 1. Berdasarkan rajah tersebut, dua blok berkenaan menunjukkan nilai dua dan blok yang berwarna tersebut dikira sebagai nilai satu. Melalui manipulasi hands-on ke atas blok- 
blok tersebut, yang juga dikenali sebagai manipulatif iaitu bahan atau objek yang dimanipulasi, aktiviti berkaitan operasi asas seperti menambah, menolak dan mendarab pecahan dapat dilakukan dalam persekitaran dunia Minecraft. Pelaksanaan aktiviti hands-on ini akan membantu mewujudkan hubungan antara aktiviti berkenaan dengan konsep pecahan yang abstrak kerana dengan berinteraksi serta melakukan aktiviti secara hands-on, kemahiran matematik murid akan dapat dipertingkatkan dan ini sekali gus membantu murid untuk memahami konsep matematik yang abstrak kerana murid dapat memvisualisasikan konsep tersebut dengan baik dalam minda (Holmes, 2013; Kontaş, 2016). Manipulasi yang dilakukan ke atas bahan manipulatif sama ada dalam bentuk objek konkrit mahupun bentuk maya berupaya membantu dalam memperkukuh pemahaman konsep matematik (Hartshorn \& Boren, 1990). Bruner (1977), Dienes (1973) dan Piaget (1965) turut menyatakan bahawa murid akan membina pengetahuan yang semakin kompleks melalui penglibatan aktif dengan bahan manipulatif. Rajah 2 menunjukkan contoh aktiviti penyelesaian masalah pecahan yang dapat disediakan oleh guru untuk dilaksanakan oleh murid di dalam persekitaran dunia maya Minecraft. Bagi menyelesaikan permasalahan berkenaan, murid perlu melakukan manipulasi hands-on terhadap kedudukan atau susunan blok tersebut dan ini dapat dilakukan dengan memecah, menambah dan menyusun blok-blok tertentu.

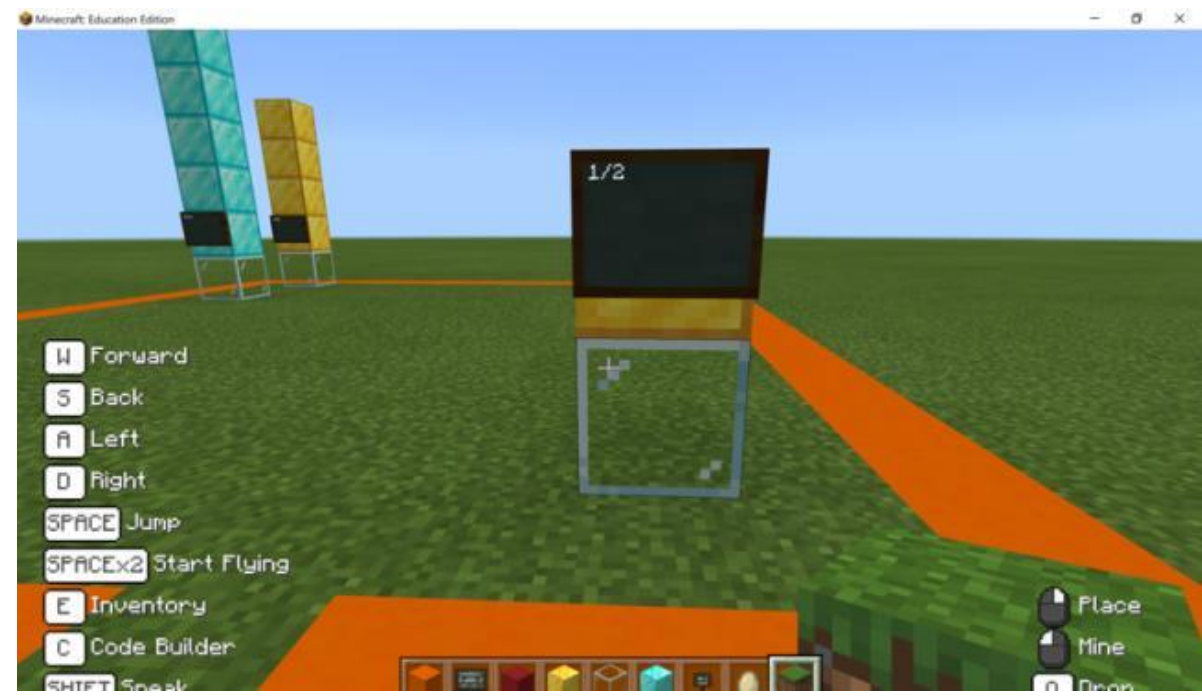

Rajah 1: Susunan blok yang membentuk nilai pecahan 'satu per dua' 


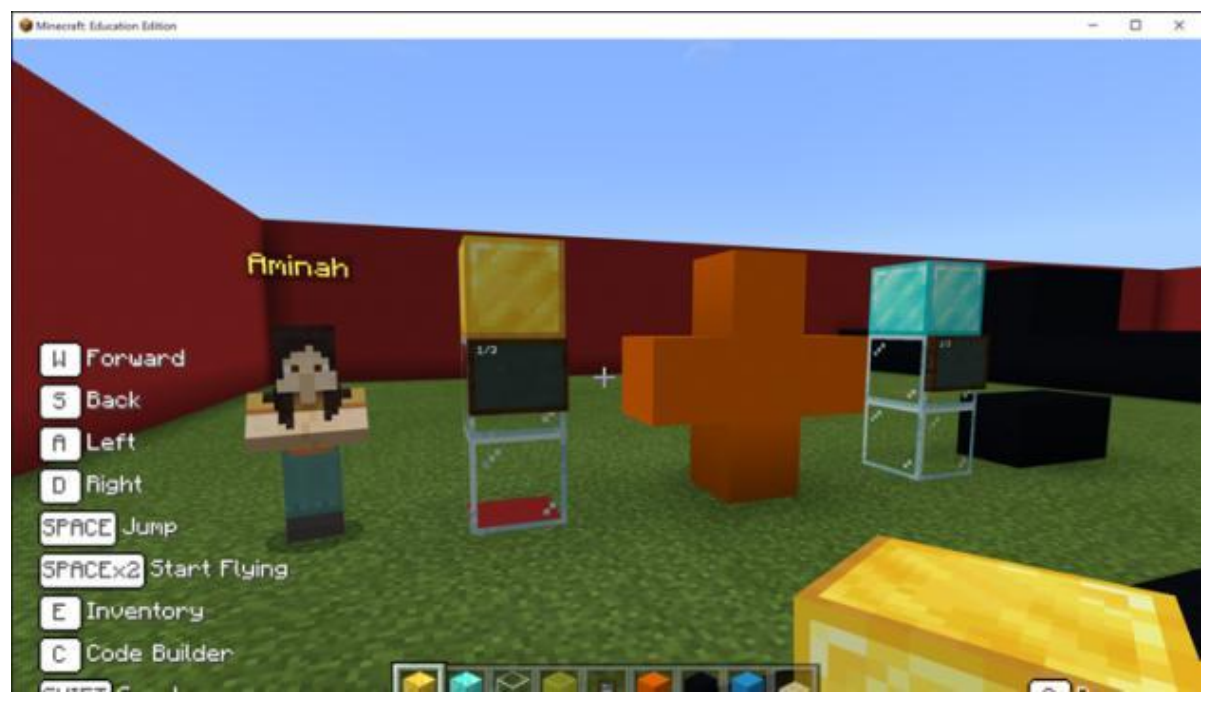

Rajah 2: Penambahan pecahan sama penyebut

\section{Kerangka Konseptual Kajian}

Kajian-kajian lepas menunjukkan bahawa pembelajaran berasaskan permainan digital adalah berkesan dalam meningkatkan pencapaian akademik murid (Yeh et. al., 2017; Chen, 2017; Siew et. al., 2016). Di samping itu, kajian-kajian lepas juga menunjukkan bahawa Minecraft telah diaplikasi sebagai alat pengajaran dalam pelbagai bidang akademik seperti STEM (Lane et. al., 2017), bahasa dan literasi (Lyngstad, 2017; Bebbington, 2014; Garcia Martinez, 2014; Hanghøj et. al., 2014), geometri (Kim \& Park, 2018; Bos et. al., 2014), penceritaan digital dan aplikasi seni komputer (Garcia Martinez, 2014), kesusasteraan (Cipollone et. al., 2014) serta kemahiran sosial (Petrov, 2014). Namun demikian, dapatan empirikal berkenaan kesan pembelajaran berasaskan permainan digital terhadap peningkatan pencapaian murid perlu diperbanyakkan (All et. al., 2017) lebih-lebih lagi kesan pembelajaran berasaskan permainan digital terhadap pencapaian pecahan melalui penggunaan Minecraft (Bos et. al., 2014). Oleh itu, objektif kertas konsep ini adalah untuk mencadang pembinaan sebuah kerangka konseptual berkaitan pembelajaran berasaskan permainan digital yang menggunakan Minecraft dalam PdPc matematik yang sesuai digunakan oleh golongan pendidik untuk mewujudkan persekitaran pembelajaran yang menggalakkan keterlibatan aktif serta memotivasikan murid untuk mengikuti pembelajaran yang kemudiannya akan meningkatkan pencapaian murid dalam pecahan.

Kerangka konseptual yang dicadang untuk kajian ini dibangunkan hasil penelitian terperinci terhadap kaedah pembelajaran berasaskan permainan digital, permainan digital Minecraft serta teori-teori pembelajaran iaitu teori main, teori connectionism, teori konstruktivisme kognitif, teori konstruktivisme sosial dan teori rangsangan deria bagi menghasilkan sebuah pakej pembelajaran yang berupaya meningkatkan pencapaian murid Tahun Lima dalam topik pecahan. Kerangka konseptual tersebut diadaptasi dari model permainan input-proses-hasil oleh Garris, Ahlers dan Driskell (2002) 
dan diubahsuai bagi memenuhi sasaran kajian ini. Model permainan input-proses-hasil dirujuk bagi membangunkan kerangka konseptual kajian ini disebabkan model ini memfokus kepada penggabungan ciri-ciri permainan (game characteristics) dengan kandungan pengajaran (instructional content), di mana permainan tersebut merujuk kepada permainan digital. Rajah 3 menunjukkan kerangka konseptual yang diadaptasi dari model permainan input-proses-hasil oleh Garris et. al. (2002).

Model permainan ini terdiri daripada tiga bahagian iaitu input, proses dan hasil. Bahagian input merujuk kepada permainan digital itu sendiri yang terdiri daripada gabungan atau integrasi kandungan pengajaran dan juga ciri-ciri permainan. Dalam kajian ini, kandungan pengajaran adalah terdiri daripada aktiviti penyelesaian masalah pecahan yang perlu dilaksanakan oleh murid permainan digital Minecraft. Semasa murid memainkan permainan digital berkenaan, mereka akan melalui proses seperti yang ditunjukkan pada 'kitaran permainan' dalam model ini. Proses yang berlaku dalam kitaran permainan ini merangkumi penilaian pengguna, tingkah laku pengguna dan maklum balas sistem. Ciri utama sebuah permainan digital yang baik adalah, sebaik sahaja pengguna memainkan permainan tersebut, pengguna berkenaan tidak akan berhenti bermain dengan serta merta tetapi akan terus memainkan permainan berkenaan berulang kali sekiranya permainan berkenaan adalah menarik, menyeronokkan dan mencetus penghayatan sehingga pengguna menjadi sangat bermotivasi dan 'ketagih' terhadap permainan tersebut (Garris et. al., 2002). Semasa permainan digital berkenaan dimainkan oleh pengguna, mereka akan membuat penilaian atau memberi rating terhadap permainan berkenaan dan menentukan sama ada permainan tersebut adalah menyeronokkan, menarik, mencetus kegembiraan atau menggalak keterlibatan. Penilaian yang positif akan menghasilkan tingkah laku yang positif dan ini akan lebih memotivasikan pengguna untuk terlibat secara aktif dalam aktiviti yang terdapat dalam permainan berkenaan. Tingkah laku pengguna ketika memainkan permainan tersebut juga dapat diperhatikan apabila mereka menunjukkan minat dan penglibatan yang lebih aktif dalam permainan. Maklum balas yang diterima oleh pengguna mengenai kemajuan mereka dalam mencapai matlamat pembelajaran akan mendorong mereka untuk meningkatkan usaha dan perhatian terhadap pelaksanaan tugasan yang terdapat di dalam permainan berkenaan. Oleh itu, objektif dan hasil pembelajaran dapat dicapai sekiranya murid terlibat secara aktif dalam melaksanakan aktiviti atau tugasan dalam permainan seperti yang ditunjukkan dalam Rajah 3. Berdasarkan konteks kajian ini, pelaksanaan PdPc yang berlaku dalam bahagian 'kitaran permainan' model ini akan merujuk teoriteori pembelajaran iaitu teori main, teori connectionism, teori konstruktivisme kognitif, teori konstruktivisme sosial serta teori rangsangan deria untuk memastikan bahawa pelaksanaan aktiviti pembelajaran berupaya mencapai matlamat yang disasarkan di akhir pembelajaran iaitu peningkatan pencapaian dalam topik pecahan. 


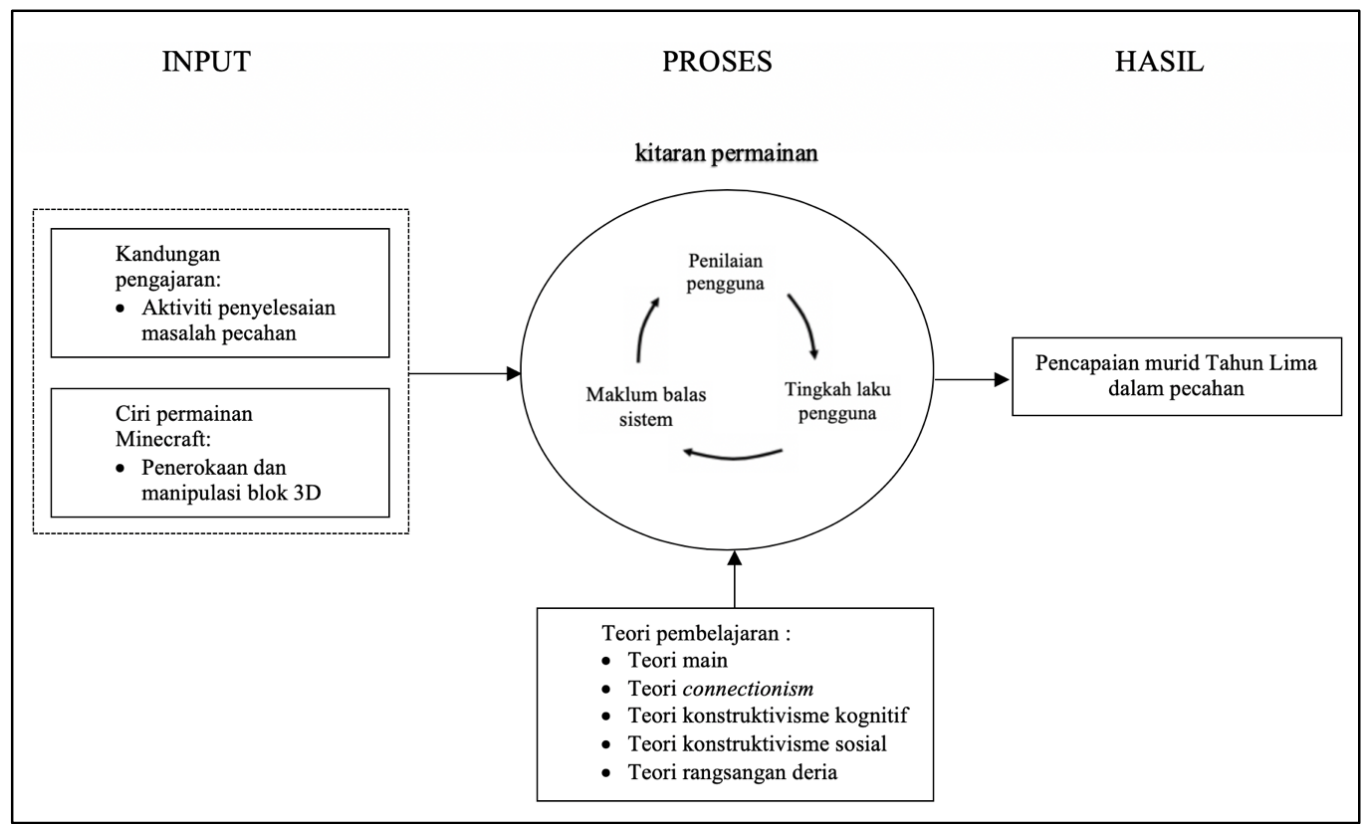

Rajah 3: Kerangka konsep pembelajaran berasaskan permainan digital menggunakan Minecraft yang diadaptasi dari Garris et. al. (2002)

\section{KESIMPULAN}

Sebagai rumusan, kertas konsep ini telah membincangkan mengenai kelebihan dan faktor yang telah mendorong kepada pengintegrasian permainan digital dalam persekitaran pendidikan khususnya dalam pelaksanaan PdPc. Melalui kertas konsep ini, kerangka konseptual pembelajaran berasaskan permainan digital telah dicadang berdasarkan teori pembelajaran dan elemen 'dunia-terbuka' Minecraft yang telah dinyatakan. Kerangka konseptual yang dicadang ini merupakan panduan dan idea yang boleh dirujuk dan oleh guru dalam mewujudkan sebuah persekitaran pembelajaran maya melalui pelaksanaan kaedah pembelajaran berasaskan permainan digital dengan matlamat untuk mempertingkat pencapaian murid dalam pecahan. Namun demikian, kajian selanjutnya perlu dijalankan bagi membuktikan keberkesanan kerangka konseptual ini.

\section{RUJUKAN}

Abdul Halim Abdullah \& Nur Liyana Zainal Abidin (2015). Analisis kesilapan pelajar dalam menyelesaikan kemahiran berfikir aras tinggi (KBAT) untuk topik pecahan. Jurnal Pendidikan Nusantara, 1, 1-17.

Abdul Halim Abdullah, Nur Liyana Zainal Abidin \& Marlina Ali. (2015). Analysis of students' errors in solving higher order thinking skills (HOTS) problems for the topic of fraction. Asian Social Science, 11(21), 133-142.

Adams, E. (2010). Fundamentals of game design: Game worlds (2nd ed.). Berkeley, CA: New Riders Publishing.

Adams, E. \& Dormans, J. (2012). Game mechanics: Advanced game design. Berkeley, CA: New Riders Publishing.

Al-Azawi, R., Al-Faliti, F. \& Al-Blushi, M. (2016). Educational gamification vs. game based learning: A comparative study. International Journal of Innovation, Management and Technology, 7(4), 132-136.

Alibali, M.W., \& Sidney, P.G. (2015). Variability in the natural number bias: Who, when, how, and why. Learning and Instruction, 37, 56-61. 
Peningkatan Pencapaian dalam Pecahan: Kerangka Konseptual untuk Pembelajaran Berasaskan Permainan Digital Menggunakan Minecraft

Received Date: 15 May 2020; Accepted Date: 02 June 2020; Published Date: 11 July 2020

All, A., Plovie, B., Nuñez Castellar, E.P. \& Van Looy, J. (2017). Pre-test influences on the effectiveness of digital-game based learning: A case study of a fire safety game. Computers \& Education, 114, 24-37.

Asselstine, S., Bloom, D., Chercka, A., Clark, A., Elford, S., Lee, D. \& York, J. (2015). Minecraft in the classroom: Ideas, inspiration, and students' projects for teachers. (C. Gallagher, Ed.). San Francisco: Peachpit Press.

Bawa, P., Watson, S.L. \& Watson, W. (2018). Motivation is a game: Massively multiplayer online games as agents of motivation in higher education. Computers \& Education, 123, 174-194.

Bebbington, S. (2014). A case study of the use of the game Minecraft and its affinity spaces for information literacy development in teen gamers. Doctoral Dissertation. University of Ottawa, Ontario: Canada.

Behnamnia, N., Amirrudin, K., \& Maizatul Akmar, I. (2020). The landscape of research on the use of digital game-based learning apps to nurture creativity among young children: A review. Thinking Skills and Creativity, 37. https://doi.org/10.1016/j.tsc.2020.100666

Behr, M., Harel, G., Post, T. \& Lesh, R. (1993). Rational numbers: Towards a symantic analysis - Emphasis on the operator construct. In: T.P. Conpenter, E. Fennema \& T.A. Romberg (Eds), Rational numbers: An integration of research, Lawrence Erlbaum Associates, Hillsdale, NJ. 13-47.

Bhuiyan, T. \& Mahmud, I. (2015). Digital game-based education: A meta analysis. In proceedings of the Internasional Conference of Inclusive Innovation and Innovative Management. 25-26 November 2015. Valaya Alongkorn Rajabhat University, Pathumthani, Thailand.

Booth, J. \& Newton, K. (2012). Fractions: Could they really be the gatekeeper's doorman? Contemporary Educational Psychology, 37, 247-253.

Bos, B., Wilder, L., Cook, M. \& O’Donnell, R. (2014). Learning mathematics through Minecraft. Teaching Children Mathematics, 21(1), 56-59.

Bruner, J. S. (1977). Process orientation. In: D.B. Aichele and R.E. Reys (Eds.), Readings in secondary school mathematics. (2nd ed.) Boston, MA: Prindle, Weber \& Schmidt.

Callaghan, N. (2016). Investigating the role of Minecraft in educational learning environments. Educational Media International, 53 (4), 244-260.

Chen, H.-R., Liao, K.-C. \& Chang, J.-J. (2015). Design of digital game-based learning system for elementary mathematics problem solving. In proceedings of the 8th Internasional Conference on Ubi-Media Computing (UMEDIA). 24-26 Ogos 2015. Colombo: Sri Lanka.

Chen, Y.-C. (2017). Empirical study on the effect of digital game-based instruction on students' learning motivation and achievement. Eurasia Journal of Mathematics, Science \& Technology Education, 13(7), 3177-3187.

Chinnappan, M. (2005). Children's mappings of part-whole construct of fractions. In: P. Clarkson \& A. Downtown (Eds.), Conference of the Mathematics Education Research Group of Australasia. 241-248. Sydney: MERGA.

Cipollone, M., Schiffer, C.C. \& Moffat, R.A. (2014). Minecraft as a creative tool. A case study. International Journal of GameBased Learning, 4(2), 1-14.

Clarke, D., Roche, A. \& Mitchell, A. (2008). Practical tips for making fractions come alive and make sense. Mathematics Teaching in the Middle School, 13(7), 372-379.

Dagar, V. \& Yadav, A. (2016). Constructivism: A paradigm for teaching \& learning. Arts \& Social Sciences Journal. 7(4), 1-4

DeWolf, M. \& Vosniadou, S. (2015). The representation of fraction magnitudes and the whole number bias reconsidered. Learning and Instruction, 37, 39-49.

Dienes, Z.P. (1973). Mathematics through the senses, games, dance and art. Windsor, UK: The National Foundation for Educational Research Publishing Company Ltd.

Ekaputra, G., Lim, C. \& Eng, K.I. (2013). Minecraft: A Game as an education and scientific learning tool. In proceedings of the Information Systems International Conference. 2-4 Disember 2013. Bali: Indonesia.

Entertainment Software Association. (2019). Essential facts about the computer and video game industry. Retrieved from https://www.theesa.com/esa-research/2019-essential-facts-about-the-computer-and-video-game-industry/

Fabricatore, C., Nussbaum, M., \& Rosas, R. (2002). Playability in video games: A qualitative design model. Human-Computer Interaction, 17(4), 311-368.

Gallagher, C. (2015). Minecraft in the classroom. Ideas, inspiration, and student projects for teachers. San Francisco: Peachpit Press.

Garcia Martinez, S. (2014). Using commercial games to support teaching in higher education. Doctoral Dissertation. Concordia University, Quebec, Canada.

Garris, R., Ahlers, R., \& Driskell, J.E. (2002). Games, motivation, and learning: A research and practice model. Simulation \& Gaming, 33(4), 441-467.

Gee, J.P. (2003). What video games have to teach us about learning and literacy. New York: Palgrave/Macmillan.

Grace, L. (2005). Game type and game genre. Retrieved from http://www.lgrace.com/documents/game_types_and genres.pdf

Hanghøj, T., Hautopp, H., Jessen, C., \& Denning, R.C. (2014). Redesigning and reframing educational scenarios for Minecraft within mother tongue education. In: I.C. Busch (Ed.), Proceedings of 8th European Conference on Games Based Learning. Reading: United Kingdom. 
Hartshorn, R. \& Boren, S. (1990). Experiential learning of mathematics: Using manipulatives. ERIC Digest. Charleston, WV: ERIC Clearinghouse on Rural Education and Small Schools. (ERIC Document Reproduction Service No. ED321967)

Holmes, A.B. (2013). Effects of Manipulative Use on PK-12 Mathematics Achievement: A Meta-Analysis. Presented in The Meeting of Society for Research in Educational Effectiveness, Washington, DC.

Huizenga, J.C. (2017). Digital game-based learning in secondary education. Doctoral Dissertation. Amsterdam: University of Amsterdam.

Hwang, G.-J., Chiu, L.-Y. \& Chen, C.-H. (2015). A contextual game-based learning approach to improving students' inquirybased learning performance in social studies courses. Computers \& Education, 81, 13 - 25

Hwang, G.-J., Hung, C.-M. \& Chen, N.-S. (2014). Improving learning achievements motivations and problem-solving skills through a peer assessment-based game development approach. Educational Technology Research and Development., 62(2), 129-145.

Hwang, G.J., Wu, P.H. \& Chen, C.C. (2012). An online game approach for improving students' learning performance in webbased problem-solving activities. Computers \& Education, 59(44), 124-1256.

Kao, G.Y.M., Chiang, C.H. \& Sun, C.T. (2017). Customizing scaffolds for game-based learning in physics: Impacts on knowledge acquisition and game design creativity. Computers \& Education, 113, 294-312.

Karsenti, T., Bugmann, J. \& Gros, P.-P. (2017). Transforming education with Minecraft? Results of an exploratory study conducted with 118 elementary-school students. Montréal: CRIFPE.

Khairuddi, N., Che Zalina, Z., Nor Azah, A.A. \& Norhisham, M.N. (2017). Reka Bentuk Gamifikasi Pembelajaran Geografi Berasaskan Permainan Geoplay. Geografi, 5(1), 46-51.

Kim, Y.R. \& Park, M.S. (2018). Creating a Virtual World for Mathematics. Journal of Education and Training Studies, 6(12), 172-183.

Kirriemuir, J. \& McFarlane, A. (2004). Report 8: Literature review in games and learning. NESTA Future lab series. Retrieved from http://www.futurelab.org.uk/download/pdfs/research/lit_reviews/Games_Review1.pdf

Kontaş, H. (2016). The effect of manipulatives on mathematics achievement and attitudes of secondary school students. Journal of Education and Learning, 5(3), 10-20.

Ku, O., Chen, S.-Y., Wu, D.-H., Lao, A.-C.-C. \& Chan, T.-W. (2014). The effects of game-based learning on mathematical confidence and performance: High ability vs. low ability. Educational Technology \& Society, 17(3), 65-78.

Lamon, S.J. (2008). Teaching Fractions and Ratios for Understanding: Essential Content Knowledge and Instructional Strategies for Teachers. New Jersey: Lawrence Erlbaum Associates.

Lane, H.C., Yi, S., Guerrero, B. \& Comins. (2017). Minecraft as a sandbox for STEM interest development: Preliminary results. In proceedings of the 25th International Conference on Computers in Education. Rydges Latimer Hotel, Christchurch: New Zealand.

Liu, E.Z.F. \& Chen, P.-K. (2013). The effect of game-based learning on student's performance in science learning - A case of "Conveyance Go". Procedia - Social and Behavioral Sciences, 103, 1044-1051.

Lyngstad, A. (2017). Sandbox games: A way to promote deeper learning in cross-curricular teaching? Master Thesis. The Artic University of Norway.

Mail, T.M. (2015). In-game Minecraft quests for elementary education. International Journal for Innovation Education and Research, 3(8), 167-174.

Minecraft Teachers. (2015). Welcome to the Google Group dedicated to helping teachers use Minecraft to facilitate learning. Retrieved from https://groups.google.com/forum/\#!forum/minecraft-teachers

Mojang. (2015). Minecraft. Retrieved from https://minecraft.net/

Mullis, I.V.S., Martin, M.O., Foy, P. \& Arora, A. (2012). TIMSS 2011 International Results in Mathematics. Chestnut Hill, MA: Boston College.

Mullis, I.V.S., Martin, M.O., Foy, P. \& Hooper, M. (2016). TIMSS 2015 International Results in Mathematics. Chestnut Hill, MA: Boston College.

Nazira, M.S., Othman, T. \& Tengku Putri Norishah. (2013). Merging of game principles and learning strategy using apps for science subjects to enhance student interest and understanding. Jurnal Teknologi, 63(2), 7-12.

Ndalichako, J. (2013). Analysis of pupils' difficulties in solving questions related to fractions: The case of primary school leaving examination in Tanzania. Creative Education, 4, 69-73.

Nebel, S., Schneider, S., \& Rey, G.D. (2016). Mining learning and crafting scientific experiments: A literature review on the use of Minecraft in education and research. Educational Technology \& Society, 19(2), 355-366.

Ni, Y. \& Zhou, Y.-D. (2005). Teaching and learning fraction and rational numbers: The origins and implications of whole number bias. Educational Psychologist, 40(1), $27-52$.

Noor Azl, M.M., Nor Azan, M.Z. \& Shamsul Bahr, C.W. (2008). Digital games-based learning for children. In proceedings of the International Symposium on Information Technology. Kuala Lumpur: Malaysia.

Nor'ain, M.T. \& Mohan, C. (2016). Relationship between scientific reasoning skills and mathematics achievement among Malaysian students. Geografia: Malaysia Journal of Society and Space, 12(1), 96-107.

Obaid, M.A.S. (2013). The impact of using multi-sensory approach for teaching students with learning disabilities. Journal of International Education Research, 9(1), 75-82. 
Peningkatan Pencapaian dalam Pecahan: Kerangka Konseptual untuk Pembelajaran Berasaskan Permainan Digital Menggunakan Minecraft

Received Date: 15 May 2020; Accepted Date: 02 June 2020; Published Date: 11 July 2020

OECD. (2010). PISA 2009 Results: What students know and can do-Student performance in reading, mathematics and science (Volume 1). OECD Publishing.

OECD. (2013). PISA 2012 Results : What students know and can do-Student performance in reading, mathematics and science. OECD Publishing.

Pantziara, M. \& Philippou, G. (2012). Levels of students' "conception" of fractions. Educational Studies in Mathematics, 79, 61-83.

Peetsma, T. \& Van der Veen, I. (2015). Influencing young adolescents' motivation in the lowest level of secondary education. Educational Review, 67(1), 97-120.

Petrov, A. (2014). Using Minecraft in education: A qualitative study on benefits and challenges of game-based education Doctoral Dissertation. University of Toronto, Canada.

Piaget, J. (1965). The child's conception of number. New York: W. W. Norton \& Company.

Prensky, M. (2001). Digital game-based learning. New York, NY: McGraw-Hill.

Rodrigues, J., Dyson, N.I., Hansen, N. \& Jordan, N.C. (2017). Preparing for algebra by building fraction sense. Teaching Exceptional Children, 49, 134-141.

Rollings, A. \& Adams, E. (2003). Andrew Rollings and Ernest Adams on game design. Indianapolis, USA: New Riders Publishing.

Sáez-López, J.-M., Miller, J., Vázquez-Cano, E. \& Domínguez-Garrido, M.-C. (2015). Exploring application, attitudes and integration of video games: MinecraftEdu in middle school. Educational Technology \& Society, 18(3), 114-128.

Sailer, M., Hense, J.U., Mayr, S.K. \& Mandl, H. (2017). How gamification motivates: An experimental study of the effects of specific game design elements on psychological need satisfaction. Computers in Human Behavior, 69, 371-380.

Saito, D., Takebayashi, A. \& Yamaura, T. (2014). Minecraft-based preparatory training for software development project. In proceedings of the International Professional Communication Conference. Carnegie Mellon University. Pittsburgh: USA.

Salen, K., \& Zimmerman, E. (2004). Rules of Play: Game Design Fundamentals. Cambridge, Massachusetts: The MIT Press.

Shabiralyani, G., Hasan, K.S., Hamad, N. \& Iqbal, N. (2015). Impact of visual aids in enhancing the learning process case research: District Dera Ghazi Khan. Journal of Education and Practice, 6(19), 226-233.

Short, D. (2012). Teaching scientific concepts using a virtual world - Minecraft. Teaching Science, 58(3), 55-58.

Siegler, R.S. \& Pyke, A.A. (2013). Developmental and individual differences in understanding of fractions. Developmental Psychology, 49, 1994-2004.

Siew Nyet Moi @ Sopiah Abdullah, Jolly Geofrey \& Lee, B.N. (2016). Students' algebraic thinking and attitudes towards algebra: The effects of game-based learning using DragonBox 12+ App. Electronic Journal of Mathematics \& Technology, $10(1), 1-17$.

Simon, M.A., Placa, N., Avitzur, A. \& Kara, M. (2018). Promoting a concept of fraction-as-measure: A study of the Learning Through Activity research program, Journal of Mathematical Behavior, 52, 122-133.

Stafylidou, S. \& Vosniadou, S. (2004). The development of students' understanding of the numerical value of fractions. Learning and Instruction, 14, 503-518.

Sung, H.Y., Hwang, G.-J., Lin, C.J. \& Hong, T.W. (2017). Experiencing the Analects of Confucius: An experiential game-based learning approach to promoting students' motivation and conception of learning. Computers \& Education, 110, 143-153.

The Star. (2019, July 21). Digital games creation can be lucrative.

Van de Walle, J.A., Karp, K.S. \& Bay-Williams, J.M. (2019). Elementary and middle school mathematics teaching developmentally. USA: Pearson Publications.

Van Hoorn, J., Nourot, P.M., Scales, B. \& Alward, K. (2007). Play at the center of the curriculum. Upper Saddle River, NJ: Merrill/Prentice Hall.

Wang, Y., Liu, X., Lin, X. \& Xiang, G. (2011). An evaluation framework for game-based learning. In proceedings of the 15th Global Chinese Conference on Computers in Education. Hangzhou, China.

Wiggins, B.E. (2016). An overview and study on the use of games, simulations, and gamification in higher education. International Journal of Game-Based Learning, 6(1), 18-29.

Wijaya, A. (2017). The relationships between Indonesian fourth graders' difficulties in fractions and the opportunity to learn fractions: A snapshot of TIMSS results. International Journal of Instruction, 10(4), 221-236.

Wong, W.S. \& Kamisah, O. (2018). Pembelajaran berasaskan permainan dalam pendidikan stem dan penguasaaan kemahiran abad ke-21. Politeknik \& Kolej Komuniti Journal of Social Sciences and Humanities, 3(1), 121-135.

Yang, Y.T.C. (2015). Virtual CEOs: A blended approach to digital gaming for enhancing higher-order thinking and academic achievement among vocational high school students Computers \& Education, 81, 281-295.

Yeh, Y., Hung, H. \& Hsu, Y. (2017). Digital game-based learning for improving students' academic achievement, learning motivation, and willingness to communicate in an english course. In proceedings of the 6th International Congress on Advanced Applied Informatics. Hamamatsu, Jepun.

Zakiah, S., Norhapidah, M.S., Mohamad Nizam, A., Hazaka, Y. \& Effandi, Z. (2013). Analisis jenis kesilapan dalam operasi penambahan dan penolakan pecahan. Jurnal Pendidikan Matematik, 1(1), 1-10. 